\title{
THE EFFECT OF AUGMENTED REALITY APPLICATIONS ON THE ACADEMIC SUCCESS OF 11TH GRADE STUDENTS IN THE CIRCULATORY SYSTEM
}

\author{
Zümrüt Karadavut ${ }^{1 i}$, \\ Osman Çimen ${ }^{2}$ \\ ${ }^{1}$ Master Teacher, \\ Ministry of Education, \\ Turkey \\ orcid.org/0000-0003-3401-0517 \\ ${ }^{2}$ Academician, \\ Gazi University, Faculty of Education, \\ Turkey \\ orcid.org/0000-0002-6651-6849
}

\begin{abstract}
:
The purpose of this study is to examine the effect of augmented reality applications on 11th grade high school students' success in circulatory system and their attitudes towards augmented reality application. The semi-experimental design was used as a research pattern. In the quantitative part of the study, semi-experimental design with pretestposttest control group was used. In the qualitative part, a case study was conducted. The sample of the study consists of 11th grade students studying in Siverek district of Şanliurfa. While the students in the experimental group learned the subject of the circulatory system with "teaching with Augmented Reality applications" the students in the control group learned with "teaching with conventional techniques". Circulatory system achievement test, attitude scale towards augmented reality practices and semistructured interviews forms were used as data collection tools in the study. The data were analyzed with SPSS 18 package programme. As a result of the study, it has been observed that augmented reality applications have a positive effect on students' academic success. When the students' opinions about teaching with augmented reality applications are examined, it is clearly seen that they have positive thoughts on the themes of using augmented reality applications to be able to see them in an easier, to increase interest and desire, to attract attention and to use technology. As a result, it was determined that augmented reality had an impact on students' achievements and attitudes.
\end{abstract}

Keywords: augmented reality applications, direct instruction method, circulatory system

i Correspondence: email zumrut.karadavut7@gmail.com 


\section{Introduction}

While explaining abstract and hard-to-understand concepts, it is really important to improve the student teaching activities visually and intellectually by making use of technology in this process, so that richer learning environments for students can be created (Akpinar et al., 2005). In this way, a learning environment in which meaningful learning is ensured and positive attitudes develop can be formed. At this point, it is considered beneficial to use the augmented reality (AR) applications, which have an important potential, in learning environments (Somyürek, 2014). One of the most important features of AR technologies is that real environment and virtual objects come together at the same time (Azuma, 1997). AR applications combine the real and virtual, provide simultaneous interaction, and also include three-dimensional objects (Azuma, 1997). With AR technology, virtual objects such as text, graphics, audio, video, animation and GPS location information are added to the real-world image (Delello, 2014).

The content of the subjects and the number of terms in the biology course is very large and there are many abstract concepts. That is why it becomes difficult for students to understand biological concepts and terms. There are many studies on students' understanding of biological concepts (Tunnicliffe \& Reiss, 1999; Bahar, Johnstone \& Hansell, 1999; Lin, 2003; Tekkaya \& Balc1, 2003; Kazanc1, 2005; Saka, 2006). When the literature is examined, it is seen that the subject of the human circulatory system is one of the biology subjects that students have difficulty in understanding, and have misconceptions (Arnaudin \& Mintzes, 1985; Yip, 1998; Tekkaya, Özkan \& Sungur, 2001). In this study, Augmented Reality applications were used to make abstract concepts about the circulatory system more meaningful for students. In this direction, it is thought that the use of augmented reality applications will be effective in increasing the success of the 11th grade students in the circulatory system and improving their positive attitudes towards the application of augmented reality.

Considering the literature, it is seen that there are very few studies investigating the effect of augmented reality applications on the teaching of biology subjects in Turkey (Küçük, 2015). However, there is no study investigating the effect of augmented reality applications on the success of the 11th grade students in the circulatory system. Considering this situation, it can be suggested that the data obtained from the research will reveal important results on the subject of the circulatory system and the use of AR applications in educational environments. In addition, the fact that large circulatory system, small circulatory system, the structure of the heart, the functioning of the heart and the shape of the heart are among the subjects that students have difficulty in learning about the circulatory system shows the importance of this research (Sungur \& Tekkaya, 2003; Tekkaya et al., 2000; Yeşilyurt \& Gül, 2012). The purpose of this study is to reveal the effect of augmented reality applications on the academic achievement of the 11th grade high school students in the circulatory system and their attitudes towards augmented reality applications. In addition, students' views on teaching with augmented 
reality applications were also examined. In line with the purpose of the research, answers to the following questions will be sought.

1) Is there a significant difference between the academic achievement scores of the experimental and control groups in the pre-test circulatory system?

2) Is there a significant difference between the academic achievement scores of the experimental and control groups in the post-test circulatory system?

3) Is there a significant difference between the academic achievement scores of the control group in the pre-test and post-test circulatory system?

4) Is there a significant difference between the academic achievement scores of the experimental group in the pre-test and post-test circulatory system?

5) What is the effect of the augmented reality applications on the attitudes of the 11th grade high school students towards the augmented reality applications among the experimental group students?

6) What are the opinions of the students in the experimental group about teaching with augmented reality applications?

For the first time, Tom Caudell had used the augmented reality applications to assist workers in their training (Caudell \& Mizell, 1992). Augmented reality applications are used in the field of education, especially because of 3D objects (Shelton, 2002). It is thought that augmented reality applications increase students' interest and motivation as they provide interaction between the real and virtual world (Chen \& Tsai, 2012). In the Horizon Report published in 2012, the augmented reality was also mentioned among the educational technologies whose use in education was expected to be of great benefit (Akt Johnson, Adams \& Cummins, 2012). When the studies conducted in Turkey on the use of augmented reality in education are examined, it is seen that the first thesis study was done by İbili (2013) in order to develop augmented reality materials for the geometry course, to apply it to the students and to investigate its effect. The augmented reality program, ARGE3D, was used. The study was carried out with a total of 100 students consisting of the 6th grade primary school students (İbili, 2013).

\section{Material and Methods}

\subsection{The Experimental Design of the Study}

The quasi-experimental design was used in this study. While the effect of the method applied in experimental research is determined by quantitative data, information and evidence about what the participants have experienced during the method process and how the method was actually processed are provided through qualitative data (Creswell, 2011). In this study, quantitative data collection tools were used to measure students' achievement and attitudes. Qualitative data of the research were collected through semistructured interviews. The circulatory system achievement test, which is a quantitative data collection tool, was applied both as a pre-test at the beginning and as a post-test at the end of the application. The augmented reality attitude scale was applied only to the students in the experimental group as a post-test at the end of the application. Semi- 
structured interviews, which are qualitative data collection tools, were used only at the end of the application.

The quantitative method applied in the study is quasi-experimental, as the students could not be randomly assigned to the experimental and research groups by being randomly selected from the population (Fraenkel \& Wallen, 2000). In the study, one of the two classes, in a public school, whose education level is 11th grade, was randomly selected as the experimental group and the other as the control group. The quasi-experimental design of the research is given in Table 1.

Table 1: Quasi-Experimental Design with Pre-test and Post-test Control Group

\begin{tabular}{|l|c|c|c|}
\hline & Pre-test & Application & Post-test \\
\hline Experimental & Achievement & Teaching with & Achievement test/ \\
Group & test & AR applications & AR attitude scale \\
\hline Control & Achievement & Teaching with direct & Achievement \\
Group & test & instruction method & Test \\
\hline
\end{tabular}

\subsection{Study Group}

The study group of the research consists of the students of the classrooms 11.I and 11.L studying at a high school in Siverek district of Şanlıurfa province in 2019-2020 academic year. The assignment of experimental and control groups from the above-mentioned classrooms was performed randomly, and 34 students of the classroom 11-I were determined as the experimental group, and 34 students of the classroom 11- $\mathrm{L}$ as the control group. The study was conducted with a total of 68 students.

\subsection{Data Collection Tools}

In the research, circulatory system achievement test, attitude scale towards augmented reality applications and semi-structured interview form were used as data collection tools.

\subsubsection{Circulatory System Achievement Test}

In order to prepare the circulatory system achievement test, a pool of 25 multiple-choice questions was created in accordance with the learning outcomes of the circulatory system for the 11th grade students. For the reliability study, the test was first applied to 130 students, of the 11th grade, with similar characteristics at another high school in Siverek. 5 questions were removed from the test by calculating their validity and reliability. The Cronbach Alpha reliability coefficient of the test was calculated as 0.81 , and the results are shown in Table 2. As a result, the Circulatory System Achievement Test consists of 20 multiple-choice questions (Appendix 1). The correct answer to each question was calculated by giving 1 point, out of 20 points. Adjustments were made in the circulatory system achievement test by receiving expert opinion during the preparation of the questions and at the end of the application. Then, it was applied as pre-test and post-test to a total of 68 students, 34 of whom were in the experimental group and 34 in the control group. 


\subsubsection{Augmented Reality Applications Attitude Scale (ARAAS)}

The Augmented Reality Applications Attitude Scale that was developed by Küçük S., Yılmaz R., Baydaş Ö. and Göktaş Y. (2014) was used in this study. The scale consists of fifteen items, nine of which are positive and six of which are negative, and three subdimensions (Appendix 2). As a result of the explanatory factor analysis performed to ensure the construct validity of the scale, a three-factor structure consisting of 15 items was obtained. The internal consistency reliability coefficient of ARAAS was found as .83 by Küçük S., Yılmaz R., Baydaş Ö. and Göktaş Y. (2014). This result shows that ARAAS is a valid and reliable measurement tool. Prior to the study, the necessary permission was obtained for the use of ARAAS.

\subsubsection{Semi-Structured Interview Form}

A semi-structured interview form was applied to 10 randomly selected students in the experimental group. The interviews were recorded with a voice recorder with the permission of the participating students. Before the interview, the students were informed about it. The questions in the interview are listed below:

- What are your general thoughts about augmented reality technology (such as its reality, usefulness)?

- What do you think are the advantages of augmented reality applications?

- Which of the augmented reality applications used in the lesson attracted your attention the most? Why?

- How do you think augmented reality technology affects your approach to biology course (interest, motivation, desire, etc.)?

- What are the problems that you face when studying with augmented reality technology? What do you think can be done about these problems?

- How did you feel when using augmented reality technology?

- Do you want augmented reality technology to be used in other subjects and courses? In which subjects or courses do you want it to be used? Why?

\subsection{Data Analysis}

The main data sources in this research are the circulatory system achievement test, the augmented reality applications attitude scale and the semi-structured interviews. Achievement test and attitude scale are quantitative data sources by their nature. Therefore, in this research, the circulatory system achievement test and the augmented reality applications attitude scale are analyzed by quantitative methods. The data was analyzed with the SPSS 18.00 program. Independent t-test was applied to examine the effect of augmented reality applications on students' academic achievement and to make statistically significant comments. Significance level was accepted as .05.

The data obtained from semi-structured interviews was analyzed by qualitative methods. After performing the augmented reality application with 10 students in the experimental group, the data obtained from the semi-structured interview forms were 
subjected to descriptive analysis in order to reveal their thoughts about the teaching process.

\section{Findings}

In the study conducted with 68 students studying in the Siverek district of Şanliurfa province, the circulatory system achievement test and augmented reality attitude scale were applied, and statistical data analyzes were made to reveal whether there was a significant difference between the experimental and control groups.

Independent groups $\mathrm{t}$-test was performed to determine whether there was a statistically significant difference between the pre-test achievement scores of the experimental and control groups. The analyzes of the obtained data are presented in Table 3.

Table 2: Independent Groups T-test Analysis of Pre-Test

Achievement Scores of Experimental and Control Groups

\begin{tabular}{|l|c|c|c|c|c|c|}
\hline Group & $\mathbf{n}$ & $\overline{\mathbf{X}}$ & $\mathbf{S D}$ & $\mathbf{t}$ & $\mathbf{d f}$ & $\mathbf{p}$ \\
\hline Experimental & 34 & 5.61 & 1.89 & 0.114 & \multirow{2}{*}{66} & 0.91 \\
\hline Control & 34 & 5.67 & 2.34 & & & \\
\hline
\end{tabular}

As a result of the test, it was found that the variances of the experimental and control groups were equal $(\mathrm{F}=2.24 ; \mathrm{p}=0.91)$. The results of the analysis showed a 0.06-point difference between the mean pre-test scores of the experimental group $(X=5.61, S D=$ $1.89)$ and the mean pre-test scores of the control group $(X=5.67, S D=2.34)$. It is seen that the difference between the mean pre-test achievement score of the experimental group and that of control group is not statistically significant ( $t(66)=0.114 \mathrm{p}>.05$ ). In other words, the results of the analysis show that the students in the experimental and control groups are equivalent to each other in terms of achievement levels in the circulatory system before the application.

Independent groups t-test was performed to determine whether there was a statistically significant difference between the pre-test and post-test achievement scores of the control group. The analyses of the obtained data are presented in Table 3.

Table 3: Independent Groups T-test Analysis of the Pre-Test and Post-Test Achievement Scores of the Control Group

\begin{tabular}{|l|c|c|c|c|c|c|}
\hline Test Type & $\mathbf{n}$ & $\overline{\mathbf{X}}$ & SD & $\mathbf{t}$ & $\mathbf{d f}$ & $\mathbf{p}$ \\
\cline { 1 - 4 } Pre-Test & 34 & 5.67 & 2.34 & \multirow{2}{*}{15.6} & \multirow{2}{*}{33} & 0.00 \\
\hline Post-Test & 34 & 15.97 & 3.13 & & & \\
\hline
\end{tabular}

When the data in Table 3 was examined, it was seen that the mean pre-test score of the circulatory system achievement test of the control group was 5.67 and the standard deviation was 2.34 while their mean post-test score was 15.97, and the standard deviation was 3.13. Considering the pre-test and post-test results, a significant difference is found 
between the circulatory system achievement scores in the control group ( $\mathrm{t}(33)=15.6$; $\mathrm{p}<.05$ ). These findings lead to the conclusion that the achievement of the control group students in the circulatory system brought about a change in the process, the application period of which was 2 weeks.

Independent groups t-test was performed to determine whether there was a statistically significant difference between the pre-test and post-test achievement scores of the experimental group. The analyses of the obtained data are presented in Table 4.

Table 4: Independent Groups T-test Analysis of the Pre-Test and Post-Test Achievement Scores of the Experimental Group

\begin{tabular}{|l|c|c|c|c|c|c|}
\hline Test Type & $\mathbf{n}$ & $\overline{\mathbf{X}}$ & SD & $\mathbf{t}$ & $\mathbf{d f}$ & $\mathbf{p}$ \\
\cline { 1 - 4 } Pre-Test & 34 & 5.61 & 1.89 & 27 & 33 & 0.00 \\
\hline Post-Test & 34 & 16.91 & 1.81 & & & \\
\hline
\end{tabular}

When the data in Table 4 was examined, it was seen that the mean pre-test score of the circulatory system achievement test of the experimental group was 5.61 and the standard deviation was 1.89 while their mean post-test score was 16.91, and the standard deviation was 1.81. There is a significant difference between the pre - test and post-test scores of the experimental group $(\mathrm{t}(33)=27 ; \mathrm{p}<.05)$. These findings lead to the conclusion that the achievement of the experimental group students in the circulatory system brought about a change in the process, the application period of which was 2 weeks.

Independent groups t-test was performed to determine whether there was a statistically significant difference between the post-test achievement scores of the experimental and control groups. The analyses of the obtained data are presented in Table 5.

Table 5: Independent Groups T-test Analysis of Post-Test Achievement Scores of Experimental and Control Groups

\begin{tabular}{|l|c|c|c|c|c|c|}
\hline Group & $\mathbf{n}$ & $\overline{\mathbf{X}}$ & $\mathbf{S D}$ & $\mathbf{t}$ & $\mathbf{d f}$ & $\mathbf{p}$ \\
\hline Experimental & 34 & 16.91 & 1.81 & \multirow{2}{*}{1.51} & \multirow{2}{*}{66} & \multirow{2}{*}{0.13} \\
\hline Control & 34 & 15.97 & 3.13 & & & \\
\hline
\end{tabular}

As a result of the test, it was found that the variances of the experimental and control groups were not equal $(\mathrm{F}=15.0 ; \mathrm{p}=0.13)$. The analysis results showed a difference of 0.94 point, in favour of the experimental group, between the post-test achievement score of the experimental group $(X=16.91, S D=1.81)$ and that of the control group $(X=15.97, S D$ $=3.13$ ). It is seen that the difference between the mean post-test achievement score of the experimental group and that of control group is not statistically significant $(t)(66)=1.51$ $\mathrm{p}>$.05). According to this result, there is no significant difference between the achievement of the experimental group taught with AR applications and the control group students taught with traditional method.

In order to determine the attitudes of the students in the experimental group towards the augmented reality applications, the "Augmented Reality Applications 
Attitude Scale" consisting of 15 items of 5-point Likert type developed by Küçük et al., (2014) was used. The items in the scale were divided into 3 categories according to the attitudes they measured, and scored according to the marking of the students. Descriptive analyses were performed according to the scores, and the attitudes of the students towards the augmented reality applications were shown in 3 separate tables as follows: using satisfaction, using anxiety and using willingness.

Table 6: Students' Attitudes Towards Satisfaction with Using the Augmented Reality Applications

\begin{tabular}{|l|c|c|c|c|}
\hline & $\mathbf{N}$ & $\overline{\mathbf{X}}$ & SD & $\mathbf{X}_{\text {total }}$ \\
\hline Item 1 & 34 & 4.55 & .70 & \\
\hline Item 2 & 34 & 4.26 & .99 & \\
\hline Item 3 & 34 & 4.67 & .53 & \\
\hline Item 4 & 34 & 4.55 & .61 & 4.47 \\
\hline Item 5 & 34 & 4.55 & .61 & \\
\hline Item 6 & 34 & 4.50 & .66 & \\
\hline Item 7 & 34 & 4.26 & .79 & \\
\hline
\end{tabular}

The mean point of the answers given by the students to the items related to "Using Anxiety", which indicates six negative statements, was calculated as 4.52 out of five points. Since this item was negative, it was calculated by giving five points to the statement "Strongly Disagree" and one point to the statement "Strongly Agree". Accordingly, it is seen that the students do not have anxiety when using the augmented reality application in the lesson.

Table 7: Students' Attitudes Towards Anxiety about Using the Augmented Reality Applications

\begin{tabular}{|l|c|c|c|c|}
\hline & $\mathbf{n}$ & $\overline{\mathbf{X}}$ & SD & $\mathbf{X}_{\text {total }}$ \\
\hline Item 8 & 34 & 4.58 & .65 & \\
\hline Item 9 & 34 & 4.61 & .55 & 4.52 \\
\hline Item 10 & 34 & 4.52 & .78 & \\
\hline Item 11 & 34 & 4.47 & .66 & \\
\hline Item 12 & 34 & 4.52 & .66 & \\
\hline Item 13 & 34 & 4.44 & .70 & \\
\hline
\end{tabular}

The mean point of the answers given by the students to the items related to "Using Anxiety", which indicates six negative statements, was calculated as 4.52 out of five points. Since this item was negative, it was calculated by giving five points to the statement "Strongly Disagree" and one point to the statement "Strongly Agree". Accordingly, it is seen that the students do not have anxiety when using the augmented reality application in the lesson.

Table 8: Students' Attitudes Towards Willingness to Use the Augmented Reality Applications

\begin{tabular}{|c|c|c|c|}
\hline $\mathbf{n}$ & $\overline{\mathbf{X}}$ & SD & $\mathbf{X}_{\text {total }}$ \\
\hline 34 & 4.61 & .65 & \multirow{2}{*}{4.62} \\
\hline 34 & 4.64 & .81 & \\
\hline
\end{tabular}


The mean point of the answers given by the students to the items related to "Using Willingness", which indicates two positive statements, was calculated as 4.62 out of five points. This clearly shows that students want to use augmented reality applications in the future and in other courses.

Table 9: Opinions of Students about Teaching with Augmented Reality Applications

\begin{tabular}{|l|l|c|c|}
\hline \multirow{4}{*}{} & Theme & $\begin{array}{c}\text { Percent } \\
\text { (\%) }\end{array}$ & $\begin{array}{c}\text { Frequency } \\
\text { (f) }\end{array}$ \\
\hline \multirow{5}{*}{ Positive } & Ease of use & 10 & 100 \\
\cline { 2 - 4 } & Seeing more clearly and understandably & 6 & 60 \\
\cline { 2 - 4 } & Increasing interest and willingness & 8 & 80 \\
\cline { 2 - 4 } & Drawing attention & 10 & 100 \\
\cline { 2 - 4 } & Using technology & 8 & 80 \\
\cline { 2 - 4 } & Active participation & 8 & 80 \\
\cline { 2 - 4 } & 3D image & 9 & 90 \\
\cline { 2 - 4 } & Realistic image & 7 & 70 \\
\hline \multirow{2}{*}{ Negative } & Not applicable to every subject & 5 & 40 \\
\cline { 2 - 4 } & Insufficiency of technology & 5 & 50 \\
\hline
\end{tabular}

10 randomly-selected students in the experimental group studying in the augmented reality group stated that the augmented reality applications were easy to use. Some sample statements related to this theme are as follows:

"I understood the subject very easily. Now I can explain these practices to someone else. I had no difficulty using augmented reality applications." (S1)

"I was able to open the applications myself and observe them easily over the phone." (S5)

"It allowed me to see the visuals in the course book close to reality without any problems. The structure of the heart and its functioning mechanism were the subjects I learned the best, and I had no difficulty. Applications were easy and understandable." (S6)

6 out of 10 students randomly-selected from the experimental group studying in the AR group stated that they could learn the subject more clearly and comprehensibly thanks to AR applications. Some sample statements related to this theme are as follows:

"I understood the subject better because the lessons were very entertaining. With "Body $4 D^{\prime \prime}$ application, I easily grasped the structure of the heart. We observed the subject of large and small circulatory system on the t-shirt on our friend. In addition, when we held the phone to the image showing the large circulatory system, we watched the audio video explaining the subject. In the same way, when we held the phone to the image showing the small circulatory system, we watched the video explaining the subject. Thanks to this, I understood this subject very well." (S3) 
"The heart caught my attention. It's the first time I've seen the heart so real. In this way, the structure of the heart became more understandable to me." (S4)

"Thanks to augmented reality applications, I understood the subject better. The lessons were very enjoyable. It was as if I had left the virtual world and returned to the real world."

"I really liked augmented reality technology. I was curious about the subject because it caught my attention. The applications were very effective to allow me to keep the subject in my mind and learn it." (S9)

8 out of 10 students randomly-selected from the experimental group studying in the augmented reality group stated that augmented reality applications were effective in increasing interest and willingness. Some of the sample statements in line with the answers given by the students are given below:

"I really liked augmented reality technology. If it is rendered common, the interest of all students in the course will increase like mine. In this way, I think that I will study more efficiently." (S1)

"I was very excited to see the features of the organs live and to open the videos when I held the application on the visuals in the textbook. My interest in the subject and the lesson increased. That's why I'm happy." (S2)

"Thanks to the augmented reality applications in the course, I was never bored. The heart and the vessels in our body became 3D thanks to the application on the phone. I even held the heart in my hand and our teacher took a picture of it and showed it to me. This increased my interest and willingness for the course even more." (S8)

"My interest in biology increased. I realized that it was a more fun lesson than I thought. We turned and observed all parts of the heart." (S10)

10 randomly-selected students in the experimental group studying in the augmented reality group stated that the augmented reality applications caught their attention. Some sample statements related to this theme are as follows:

"The fact that the heart picture in the book was shown in 3D and explained with videos caught my attention the most. It was very enjoyable to see the chambers of the heart, arteries and veins more closely." (S3) 
"There was a picture showing the large and small circulatory system on the T-shirt. When I held the phone to the $t$-shirt with the augmented reality application, the video explaining the subject appeared. For the first time, I've seen such a thing." (S4)

"It was remarkable to see the heart in my hand 3D through "Body $4 D$ " application. It was very fun for me. At every stage of the course, I waited with curiosity what kind of application we would do now." (S6)

"Seeing the chambers of the heart and the aorta in detail attracted my attention the most." (S7)

8 out of 10 students randomly-selected from the experimental group studying in the augmented reality group had positive statements about the use of technology. Some sample statements related to this theme are as follows:

"It was a great feeling to use the technology in the lesson. Thanks to technology, I learned more about the subject. And it was a great advantage that it was easy to use." (S1)

"When I listen to the lesson only from the teacher, I can get distracted after a while. I do not experience this situation with the use of technology in the classroom. It has been very useful to me in this sense. I'd like it to be used in all classes." (S2)

"I learned the visuals of the books in detail with the HP Reveal application. This was thanks to the use of technology in the lesson. The subject of the course caught my attention more because of this. Technology should now be used in all our lessons." (S8)

"I see the heart picture in the textbooks. But I've never seen it in 3D. I learnt it that it was because of "Body 4D" application. It's all thanks to technology. I think using technology in lessons is very beneficial for students." (S9)

8 out of 10 students randomly-selected from the experimental group studying in the augmented reality group stated that they actively participated in the lesson taught with augmented reality applications. Some sample statements related to this theme are as follows:

"It made me more active in the lesson. That way I can learn easily. It changed my views on the course in a positive sense." (S4)

"It made me follow the lesson better and more actively. The lesson was more fun and enjoyable. AR applications put me in an active mode, and not in a sleepy mode." (S5) 
"I felt that I was more active in the lesson because I personally did the augmented reality applications in the lesson. It allowed me to keep the topics in my mind and get more efficiency." (S8)

"I saw the heart in my hand in 3D using "Body 4D" application. I used all these AR applications in the course by doing and experiencing. Thanks to this, I felt more active during the lesson. This made me happy." (S10)

9 out of 10 students randomly-selected from the experimental group studying in the augmented reality group had positive statements about the theme of 3-dimensional image formation in AR applications. Some sample statements related to this theme are as follows:

"I was most impressed by the fact that the heart picture in the book was shown in 3D and explained with videos." (S1)

"The fact that the photo became 3D on the phone increased my interest in the lesson. I had the opportunity to see the heart and the vessels in detail. (S2)

"A simple photograph officially came to life thanks to the augmented reality application. This made me very excited." (S3)

"There were some visuals on the book. When I held the camera of the augmented reality application on the phone to the images, I was very surprised to see them in 3D." (S6)

7 out of 10 students randomly-selected from the experimental group studying in the augmented reality group had positive statements that AR applications provided a realistic image. Some sample statements related to this theme are as follows:

"The heart image caught my attention. That is because it is the first time I've seen the heart so real." (S4)

"I was very excited that the images were realistic when using augmented reality applications. This is the first time I've seen such a realistic technology." (S7)

"I saw the structures related to the circulatory system as if they really existed in the classroom. We saw the heart, the vessels ins in the structure of the heart, and the vessels in our body in the classroom environment. It was so realistic that we were even photographed with the heart." (S8)

"Seeing the organs visually and audibly enabled them to be kept in mind. Thanks to AR applications, I both saw the structures in the circulatory system as if they were real, and 
listened to the information about these structures. Thanks to this, I understood the topic better." (S9)

4 out of 10 students randomly selected from the experimental group studying in the augmented reality group had negative statements about the inability to apply augmented reality applications to every subject. Some sample statements related to this theme are as follows:

"I would like to use the augmented reality application in physics, chemistry and mathematics courses. But I have never seen such an application in every lesson and subject. I would like to use augmented reality applications for all subjects." (S3)

"In the biology course, we saw different augmented reality applications related to the structure of the heart, and large and small circulatory systems. But I don't think it can be applied to every subject in biology course." (S6)

5 out of 10 students randomly selected from the experimental group studying in the augmented reality group had negative statements about the insufficiency of technology in the use of AR applications. Some sample statements related to this theme are as follows:

"I think every student should have a tablet. Because when you stick to a source, it progresses group by group. This may cause some confusion." (S1)

"Better improvements can be made regarding the augmented reality applications. I wish my own phone or tablet had these applications and I could spend more time." (S4)

"Sometimes technical problems may occur while using the augmented reality applications. For example, the image on the application may not be detected by the camera immediately."

\section{Results and Discussion}

In this study, the effects of the augmented reality applications on the academic success of the students in the circulatory system in the 11th Grade Biology course, and on their attitudes towards the augmented reality applications, and the results were examined by making semi-structured interviews with the students. The results of the studies carried out for this purpose are as follows:

Prior to application, an achievement test was prepared and applied to 130 students at a high school in Siverek. According to the data obtained, its reliability and validity were calculated by receiving expert opinion. When the scores of the pre-tests applied to the experimental and control groups are analysed, there is no statistically significant 
difference in the pre-test results. This situation shows us that the knowledge levels of the groups about the Biology lesson "Circulatory System" before the application were similar. After the application, the subject of the circulatory system was taught with the direct instruction method, and the post-test was applied to the control group students. When the pre-test and post-test scores of the control group were analysed, a statistically significant difference was found between the groups. This shows that it has a positive effect on the academic achievement of the control group students, for whom the circulatory system subject is taught with the direct instruction method. After the application, the subject of circulatory system was taught with the augmented reality applications, and a post-test was applied to the experimental group students. When the pre-test and post-test scores of the experimental group were analysed, a statistically significant difference was found between the groups. This shows that the augmented reality applications have a positive effect on the academic achievement of the experimental group students, for whom the circulatory system subject is taught with these applications.

It was concluded that the post-test achievements of the students in the experimental group, who were included in the teaching process with augmented reality applications, in the circulatory system were not significantly different compared to the post-test achievements of the control group students, who were included in the teaching process with the direct instruction method. This may be due to the fact that the achievement levels of the students in both the control and experimental groups of the study were high and equal to each other. In addition, the reasons such as "difficulty of holding both the pointer and the phone" encountered by the experimental group taught with the augmented reality applications may have affected it.

There are also some studies that concluded that augmented reality applications do not positively affect the academic achievement of students. Çetin (2019) used the material that she developed with the AR application in the lessons, and observed that the use of the AR application did not have a significant effect on the academic achievement of the students. Erbaş (2016) concluded that the mobile augmented reality applications do not make a significant difference in the academic achievement of students. Gün and Atasoy (2017) concluded that the applications of augmented reality in mathematics lessons did not have a positive effect on the academic achievement of students. Yen et al. (2012) explained the phases of the moon to university students with an augmented reality application and stated that there was no significant difference in the academic achievement of the students. The results reported by these researchers support the results of this study.

Some of the studies reviewed in the literature show that augmented reality applications have a positive effect on students' achievement (Kırıkkaya \& Şentürk 2018; Özdemir, 2017; Özdemir et al., 2018; Sırakaya, 2015; Şahin, 2017; Yıldırım, 2018; Abdüsselam \& Karal 2012; Demirel, 2017; Eroğlu, 2018). Some of the reasons for the success of augmented reality applications, e.g. providing a fun learning environment 
(Erbaş, 2016; Korucu et al., 2016) and encountering a new technology by students (Küçük, 2015), may have had a positive effect.

After the application, the students' attitude scale towards augmented reality applications was applied as a post-test to the experimental group students who were taught using the augmented reality application. When the data on the augmented reality applications was examined, it was determined that the students were satisfied with the use of the augmented reality applications, and they did not have any anxiety when using the augmented reality applications. At the same time, it was found that they wanted to use augmented reality applications in other courses. There are some theses that are parallel to the results of the study (Yusoff \& Dahlan, 2013; Chang \& Liu, 2013). According to these results, Yusoff and Dahlan (2013) observed in their research that AR has the ability to attract attention. In addition, they concluded that the students were more willing to participate in the course thanks to augmented reality applications. The use of augmented reality applications is considered to be enjoyable for students. It is seen that there are also studies stating that augmented reality technology is easy to use for students (Chang \& Liu, 2013) and that students want to use augmented reality applications again and that they are satisfied with the use of AR applications (Özarslan, 2013; Gün, 2014; Taşkıran et al., 2015).

In augmented reality applications, it can be perceived as magic by students because of the 3-dimensional appearance of the visuals on the pointers (Billinghurst, Kato \& Poupyrev, 2001). Atasoy, Gün Tosik and Kocaman Karoğlu (2017) examined the attitudes and motivation levels of secondary school students towards AR applications. In their study, a positive relationship was found between attitudes and motivation levels. İzgi Onbaşılı (2018) investigated the effects of AR applications on students' attitudes and motivations. It was concluded that there is a positive relationship between students' AR attitudes and their motivation. When these results are examined, it is seen that they are in harmony with the results of the study. The views of the students who were involved in the teaching process with augmented reality applications were revealed through semistructured interviews after the application. It is seen that the frequency is $100 \%$ in the table created with the participation of 10 students within the scope of the theme of "ease of use". According to this result, the fact that the applications have a detailed content, that Body 4D and Hp Reveal applications can be opened easily on a mobile device and that students have the opportunity to observe individually show that they have a facilitating effect on learning. It seems to be in harmony with the studies supporting this in the literature (Wojciechowski \& Cellary 2013; Taşkıran et al., 2015).

When we look at the theme of "Seeing more clearly and understandably" in the semi-structured interviews with augmented reality applications, $60 \%$ of the students think that the applications provide a fun teaching environment, the time is productive and enjoyable during the lesson, and the attention of the students is attracted, all of which make the subject more clear and understandable. When the students' opinions on the theme of 'increasing interest and willingness' are examined, $80 \%$ of them state that the subject, which is explained with augmented reality applications, has increased their 
interest and willingness. When the students' opinions on the theme of "drawing attention" were examined, $100 \%$ of them stated that augmented reality applications attracted their attention and thus they found the lesson more enjoyable. When the literature is examined, it is seen that the study is in harmony with the studies showing that the augmented reality applications are found remarkable by the students due to these features (Wojciechowski \& Cellary, 2013; Andujar et al., 2010; Bujak et al., 2013).

When the students' opinions on the theme of "use of technology" were examined, $80 \%$ of the students stated that they learned the subject in more detail and found it very useful because it attracted their attention thanks to the use of technology. Considering the students' views on the "active participation" theme, $80 \%$ of them stated that they were more active in the lesson thanks to augmented reality applications. They stated that the lesson was fun, they got more efficiency and therefore they were happy when they actively participated. Examining the opinions of the students on the theme of "3dimensional image", $90 \%$ of them mentioned that the augmented reality applications providing 3D images increased their interest in the lesson and caused excitement. Considering the students' views on the theme of "realistic image", $70 \%$ of the 10 participants stated that they understood the lesson better and were able to keep it in their mind more thanks to the augmented reality applications providing realistic images. When the students' views on the theme of "not applicable to every subject" were examined, $40 \%$ of the participants stated that augmented reality applications could not be applied to every subject, and they wanted to see augmented reality applications in all lessons. When the students' opinions on the theme of "insufficiency of technology" were examined, $50 \%$ of the participants said that technology was insufficient in the augmented reality applications. In particular, they mentioned the negative aspects of not having a tablet by each student.

\section{Recommendations}

Based on the findings of this study, recommendations related to the augmented reality applications can be presented.

- In the study, it was seen that the augmented reality applications attracted the attention of the students and they developed a positive attitude towards the augmented reality applications. For this reason, augmented reality applications can be used in all courses.

- Augmented reality applications can be adversely affected by factors such as the light of the environment, the internet reception, and the camera features. In order to prevent these situations, an augmented reality application class can be opened in each school. Augmented reality glasses can be used in these classes.

- While this study was being conducted, it was observed that the students did not have any knowledge about augmented reality applications. In order for augmented reality applications to be widely used in lessons, teachers can be trained by the Ministry of National Education and augmented reality applications 
can be included in the textbooks. Thus, students can gain knowledge about augmented reality and the ability to use augmented reality applications.

- One of the shortcomings associated with augmented reality applications is the lack of augmented reality applications that are easily accessible by teachers and the lack of tablets, computers and 3D glasses necessary to use these applications. For this reason, the necessary infrastructure and equipment should be provided for teaching with augmented reality applications in schools. In addition, augmented reality applications can be included in biology textbooks.

- Augmented reality applications are adversely affected by physical factors such as light of environment, the print quality of the pointer, or the absence of a tablet possessed by each student. In order to avoid the problems arising from the situations mentioned during the application process, each student can be provided with a tablet and a pointer image and they can be observed at the same time.

- While the students were using the augmented reality applications, the fact that the programs were in foreign languages made it difficult for the students to use the application. The Turkish language support of the applications can be developed and students can access them more easily. The number of augmented reality applications that do not need the Internet can be increased.

\title{
Conflict of Interest Statement
}

The authors declare no conflicts of interests.

\begin{abstract}
About the Author(s)
Ms. Zümrüt Karadavut majored in the study of biology education, and her academic interests include applicable technologies on biological studies. In her master's thesis, Karadavut analyzed effect of augmented reality applications on eleventh level students. She currently works as teacher of sciences at secondary school.

Mr. Osman Cimen majored in the study of biology education at Gazi University. He graduated from Maths and Science Education at Gazi University. His areas of studies are about education. He is advisor of many dissertations about education. He has articles published in journals that entered SCI, SSCI and AHCI indexes. He is currently associate professor at Gazi University, Turkey.
\end{abstract}

\section{References}

Abdüsselam, M. S. \& Karal, H. (2012). Fizik öğretiminde artırılmış gerçeklik ortamlarının öğrenci akademik başarısı üzerine etkisi: 11. Sınıf manyetizma konusu örneği. Ĕ̆itim ve Öğretim Araştırmaları Dergisi, 1(4), 170-181.

Akgün, Ş. (2000). Öğretmen ve Adaylarına Fen Bilgisi Öğretimi (6.Bask1). Ankara: PegemA Yayıncilik. 
Akpınar, E., Aktamış, H. \& Ergin, Ö. (2005). Fen bilgisi dersinde eğitim teknolojisi kullanılmasına ilişkin öğrenci görüşleri. The Turkish Online Journal of Educational Technology, 4(1), 93-100.

Andujar, J. M., Mejías, A., \& Márquez, M. A. (2010). Augmented reality for the improvement of remote laboratories: an augmented remote laboratory. IEEE Transactions on Education, 54(3), 492-500.

Arnaudin, M. W., \& Mintzes, J. J. (1985). Students' alternative conceptions of the human circulatory system: a cross-age study. Science Education, 69(5), 721-733.

Atasoy, B., Tosik-Gün, E. \& Kocaman-Karoğlu, A. (2017). İlköğretim öğrencilerinin artırılmış gerçeklik uygulamalarına karşı tutumlarının ve güdülenme durumlarının belirlenmesi. Ahi Evran Üniversitesi Kırşehir Ĕ̆gitim Fakültesi Dergisi (KEFAD), 18(2), 435-448.

Azuma, R. (1997). A survey of augmented reality. Presence: Teleoperators and Virtual Environments, 6(4), 355-385.

Bahar, M., Johnstone, A. H., \& Hansell, M. H. (1999). Revisiting learning difficulties in biology. Journal of Biological Education, 33, 84-86.

Bilaloğlu, R. G. (2014). Okul öncesi dönemde fen eğitimi ve etkinlik örnekleri (2.Bask1). Ankara: Vize Yayıncilık.

Billinghurst, M., Kato, H., \& Poupyrev, I. (2001). The MagicBook: A transitional AR interface. Computers $\mathcal{E}$ Graphics, 25(5), 745-753.

Bujak, K. R., Radu, I., Catrambone, R., MacIntyre, B., Zheng, R., \& Golubski, G. (2013). A psychological perspective on augmented reality in the mathematics classroom. Computers E Education, 68, 536-544.

Büyükkaragöz, S. S. ve Çivi, C. (1997). Genel öğretim metotları. İstanbul: Öz Eğitim Yayıncilık.

Caudell, T. P., \& Mizell, D. W. (1992). Augmented reality: An application of heads-up display technology to manual manufacturing processes. Twenty-Fifth Hawaii International Conference, Hawaii.

Chang, Y. H., \& Liu, J. (2013). Applying an AR technique to enhance situated heritage learning in a ubiquitous learning environment. The Turkish Online Journal of Educational Technology, 12(3), 21-32.

Chen, C. M., \& Tsai, Y. N. (2012). Interactive augmented reality system for enhancing library instruction in elementary schools. Computers $\mathcal{E}$ Education, 59(2), 638-652.

Creswell, J. W. (2011). Educational Research: Planning, conducting, and evaluating quantitative and qualitative research (4th Ed.). Boston, MA: Pearson Education.

Çetin, Ş. (2019). Öğretimi planlamaya yönelik tutum ölçeği geçerlik ve güvenirlik çalışması. Üçüncü Sektör Sosyal Ekonomi Dergisi, 54(1), 164-177.

Delello, J. A. (2014). Insights from pre-service teachers using science-based augmented reality. Journal of Computers in Education, 1(4), 295-311.

Demirel, T. (2017). Argümantasyon yöntemi destekli artırılmış gerçeklik uygulamalarının akademik başarı, eleştirel düşünme becerisi, fen ve teknoloji dersine yönelik güdülenme ve 
argümantasyon becerisi üzerindeki etkisinin incelenmesi. Doktora Tezi, Çukurova Üniversitesi Sosyal Bilimler Enstitüsü;, Adana.

Erbaş, Ç. (2016). Mobil artırılmış gerçeklik uygulamalarının öğrencilerin akademik başarı ve motivasyonuna etkisi. Yüksek Lisans Tezi, Süleyman Demirel Üniversitesi Eğitim Bilimleri Enstitüsü, Isparta.

Eroğlu, B. (2018). Ortaokul öğrencilerine astronomi kavramlarının artırılmış gerçeklik uygulamaları ile öğretiminin değerlendirilmesi. Yüksek Lisans Tezi, Karadeniz Teknik Üniversitesi Eğitim Bilimleri Enstitüsü, Trabzon.

Fraenkel, J. R., \& Wallen, W. E. (2000). How to design and evaluate educational research (4th Ed.). Boston, Ma: Mc-Graw-Hill Companies.

Gün, E. (2014). Artırılmış gerçeklik uygulamalarının öğrencilerin uzamsal yeteneklerine etkisi. Yüksek Lisans Tezi, Gazi Üniversitesi Eğitim Bilimleri Enstisüsü, Ankara.

Gün, T. E. \& Atasoy, B. (2017). The effects of augmented reality on elementary school students' spatial ability and academic achievement. Ĕ̆itim ve Bilim Dergisi 42(191), 31-51.

Goldworthy, A. (2000). Teaching Students How to İnvestigate, Paper Presented at the Annual Meeting of Science Conference, Nicosia, Cyprus.

Hançer, A. H., Şensoy, Ö. Ve Yıldırım, H. İ. (2003). İlköğretimde çağdaş fen bilgisi öğretiminin önemi ve nasıl olması gerektiği üzerine bir değerlendirme. Pamukkale Üniversitesi Eğitim Fakültesi Dergisi, 13(13), 80.88.

Hesapçıŏlu, M. (2010). Öğretim İlke ve Yöntemleri. Ankara: Nobel Yayınları.

İbili, E. (2013). Geometri dersi için artırılmış gerçeklik materyallerinin geliştirilmesi, uygulanması ve etkisinin değerlendirilmesi. Doktora tezi, Gazi Üniversitesi Ĕ̆itim Bilimleri Enstitüsü, Ankara.

Johnson, L., Adams, S., \& Cummins, M. (2012). NMC horizon report: 2012 higher education edition. Austin, Texas: The New Media Consortium.

Kazancı M., Bora, D. N. \& Katırcıoğlu, H., (2005). Mayoz bölünme konusunun öğrencilerdeki anlamlı öğrenme düzeyinin kelime çağrışım testi ile araştırılması. Eurasian Journal of Educational Research, 21, 146 - 154.

Kırıkkaya, E. B. \& Şentürk, M. (2018). Güneş Sistemi ve Ötesi ünitesinde Artırılmış Gerçeklik Teknolojisi kullanılmasının öğrenci akademik başarısına etkisi. Kastamonu Ĕ̆itim Dergisi, 26(1), 181.

Korucu, A.T., Gençtürk, T. \& Sezer, C. (2016). Artırılmış Gerçeklik uygulamalarının öğrencilerin akademik başarı ve derse yönelik tutumlarına etkisi. XVIII. Akademik Bilişim Konferansı, Aydın.

Küçük, S. (2015). Mobil artırılmış gerçeklikle anatomi öğreniminin tıp öğrencilerinin akademik başarıları ile bilişsel yüklerine etkisi ve öğrencilerin uygulamaya yönelik görüşleri. Doktora tezi, Atatürk Üniversitesi Eğitim Bilimleri Enstitüsü, Erzurum.

Küçük, S., Yılmaz, R. M., Baydaş, Ö. \& Göktaş, Y. (2014). Ortaokullarda Artırılmış Gerçeklik uygulamaları tutum ölçeği: Geçerlik ve güvenirlik çalışması. Eğitim ve Bilim dergisi, 39 (176), 383-392. 
Lin, C., \& Yu, R. (2003). Students understanding of energy flow and matter cycling in the context of the food chain, photosynthesis and respiration. International Journal of Science Education, 25(12), 1529-1544.

Onbaşılı, Ü. İ. (2018). Artırılmış Gerçeklik uygulamalarının ilkokul öğrencilerinin Artırılmış Gerçeklik uygulamalarına yönelik tutumlarına ve fen motivasyonlarına etkisi. Ege Ĕ̆itim Dergisi, 19(1), 320-337.

Özarslan, Y. (2013). Genişletilmiş gerçeklik ile zenginleştirilmiş öğrenme materyallerinin öğrenen başarısı ve memnuniyeti üzerindeki etkisi. Doktora Tezi, Anandolu Üniversitesi Sosyal Bilimler Enstitüsü, Eskişehir.

Özdemir, M. (2017). Artırılmış Gerçeklik teknolojisi ile öğrenmeye yönelik deneysel çalışmalar: Sistematik bir inceleme. Mersin Üniversitesi Eğitim Fakültesi Dergisi, 13(2), 609-632.

Özdemir, M., Şahin, C., Arcagok, S. \& Demir, M. K. (2018). The effect of Augmented Reality applications in the learning process: A Meta-Analysis study. Eurasian Journal of Educational Research, 74, 165-186.

Saka. A., Cerrah. L., Akdeniz, A. R. \& Ayas, A. (2006). A cross-age study of the understanding of three genetic concepts: how do they image the gene, DNA and chromosomes. Journal of Science Education and Technology, 15(2), s10956-006- 90066.

Shelton, B. E. (2002). Augmented Reality and education: Current projects and the potential for classroom learning. New Horizons for Learning, 9,(1).

Sırakaya, M. (2015). Artırılmış gerçeklik uygulamalarının öğrencilerin akademik başarıları, kavram yanılgıları ve derse katılımlarına etkisi. Doktora Tezi, Gazi Üniversitesi Eğitim Bilimleri Enstitüsü, Ankara.

Somyürek, S. (2014). Öğretim sürecinde z kuşağının dikkatini çekme: Artırılmış Gerçeklik. Eğitim Teknolojisi Kuram ve Uygulama, 4(1), 63-80.

Sungur, S. \& Tekkaya, C. (2003). Student achievement in human circulatory system unit: The effect of reasoning ability and gender. Journal of Science Education and Technology, 12(1), 59-64.

Şahin, D. (2017). Artırılmış gerçeklik teknolojisi ile yapılan fen öğretiminin ortaokul öğrencilerinin başarılarına ve derse karşı tutumlarına etkisi. Yüksek Lisans Tezi, Atatürk Üniversitesi Eğitim Bilimleri Enstitüsü, Erzurum.

Taşkıran, A., Koral, E. \& Bozkurt, A. (2015). Artırılmış gerçeklik uygulamasının yabancı dil eğitiminde kullanılması. Akademik Bilişim 15'de sunulan bildiri, Anadolu Üniversitesi, Eskişehir.

Tekkaya, C., \& Balcı, S. (2003). Öğrencilerin fotosentez ve bitkilerde solunum konularındaki kavram yanılgılarının saptanması. Hacettepe Üniversitesi Ĕ̆itim Fakültesi Dergisi. 24, 101-107.

Tekkaya, C., Çapa, Y. \& Yılmaz, Ö. (2000). Biyoloji öğretmen adaylarının genel biyoloji konularındaki kavram yanılgıları. Hacettepe Üniversitesi Ĕ̆gitim Fakültesi Dergisi, 18, 140-147. 
Tekkaya C., Özkan Ö. \& Sungur S. (2001). Lise öğrencilerinin zor olarak algıladıkları biyoloji kavramları. Hacettepe Üniversitesi Eğitim Fakültesi Dergisi 21, 145-150.

Tunnicliffe, S. D. and Reiss, M. J. (1999). Students' understanding about animal skeletons. International Journal of Science Education, 21, 1187-1200.

Wojciechowski, R., \& Cellary, W. (2013). Evaluation of learners' attitude toward learning in ARIES augmented reality environments. Computers $\mathcal{E}$ Education, (68), 570-585.

Yen J. C., Tsai C. H., \& Wang J. Y. (2012). The effects of Augmented Reality on students' moon phases concept learning and their conceptual changes of misconception. International Conference on Business and Information, Sapporo, Japan.

Yeşilyurt, S. \& Gül, Ş. (2012). Ortaöğretim öğrencilerinin taşıma ve dolaşım sistemleri ünitesi ile ilgili kavram yanılgıları. Kuramsal Ĕ̆itim Bilim Dergisi, 5(1); 17-48.

Yıldırım, P. (2018). Mobil artırılmış gerçeklik teknolojisi ile yapılan fen öğretiminin ortaokul öğrencilerinin fen ve teknolojiye yönelik tutumlarma ve akademik başarılarına etkisi. Yüksek lisans tezi, Firat Üniversitesi Eğitim Bilimleri Enstitüsü, Elazığ.

Yip, D. Y. (1998). Teachers' misconceptions of the circulatory system. Journal of Biological Education, 32(3), 207-216.

Yusoff, Z., \& Dahlan, H. M. (Kasım, 2013). Mobile based learning: An integrated framework to support learning engagement through Augmented Reality environment. Research and Innovation in Information Systems (ICRIIS), 2013 International Conference'da sunulmuş bildiri, Kuala Lumpur. 


\section{Appendices}

Appendix 1: The 11th Grade Circulatory System Achievement Test

Name Surname:

Class:

No:

Score:

1) Which of the following vessels does not the blood pass through in the human large circulatory system?
A) Aortic artery,
B) Pulmonary artery,
C) Renal artery,
D) Upper main vein,
E) Hepatic artery.

2) Which of the following vessels supplies the heart with nutrients and oxygen?
A) Aortic artery,
B) Coronary vessels,
C) Pulmonary artery,
D) Lower main vein,
E) Pulmonary vein.

3) Which of the following statements about the structure of the human heart is wrong?

A) There is a triple valve between the right atrium and the right ventricle, and a double valve between the left atrium and the left ventricle.

B)The left ventricular wall is relatively thicker than the right ventricular wall.

C) The heart consists of the endocardium, pericardium, and myocardium from the outside to the inside.

D) On the right side of the heart is oxygen-poor, carbon dioxide-rich blood.

E) The aortic artery leaves the left ventricle of the heart and distributes blood throughout the body.

4) Regarding the structure of the heart

a) Myocardium is the innermost layer of the heart walls.

b) The pericardium, which covers the outside of the heart, is a double-layered membrane that contains fluid between it.

c) The bundles of sensation that carry impulses to the ventricles are specialized muscle fibres. 
4) Which of the statements above is correct?
A) Only a)
B) Only b)
C) Only c)
D) a) and b)
E) b) and c)

5) Regarding the large circulatory system:
a) It is between the heart and the lungs.
b) It starts in the left ventricle of the heart and ends in the right atrium.
c) Arteries in the large circulatory system carry oxygen-rich blood.

Which of the statements above is correct?
A) Only a)
B) Only c)
C) a) and b)
D) b) and c)
E) a), b) and c)

6) Some parts of the human heart are schematized below.

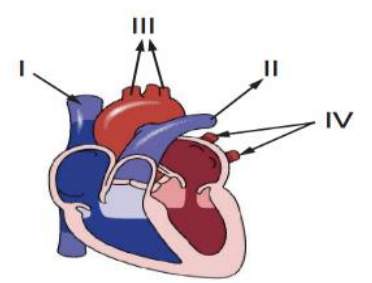

Which of the following cannot be said about the numbered parts?
A) II and III are the arteries that carry blood away from the heart.
B) I and IV are the veins that bring blood to the heart.
C) Small circulatory system begins with II, ends with IV.
D) Large circulatory system begins with III, ends with I.
E) II is the pulmonary vein that carries oxygen-poor blood.

7) Which of the following vessels does not contain oxygen-rich blood?
A) Hepatic artery
B) Pulmonary vein
C) Renal artery
D) Pulmonary artery
E) Aortic artery

8) Which of the following statements about coronary vessels in the heart structure is wrong?
A) They take blood from the aortic artery.
B) Their narrowing and blockage leads to a heart attack. 
C) It leaves the left atrium of the heart and distributes blood throughout the body.

D) It provides nutrition to the heart.

E) It supplies blood to the heart's own muscles.

9) Which of the following does not occur when the ventricles of the heart contract in a healthy person?

a) Oxygen-rich blood is pumped into the aortic artery.

b) Oxygen-poor blood is pumped into the pulmonary artery.

c) The blood in the atria is discharged into the ventricles.
A) Only a),
B) Only b),
C) Only c),
D) a) and c),
E) b) and c).

10) Which of the following is performed by the small circulatory system in humans?
A) Distributing oxygen-rich blood throughout the body,
B) Sending nutrients to tissue cells outside the lung,
C) Enriching the blood with oxygen in the lungs,
D) Accelerating the heartbeat,
E) Returning the oxygen-poor blood to the heart by veins.

11) Which of the following does not occur during the contraction of the ventricles in the human heart?
A) Relaxation of the right atrium,
B) Opening of the bicuspid valve,
C) Filling of oxygen-rich blood into the left atrium,
D) Pumping of the oxygen-poor blood into the lung,
E) Supply of the myocardial layer by coronary vessels.

12) The human heart is schematized below.

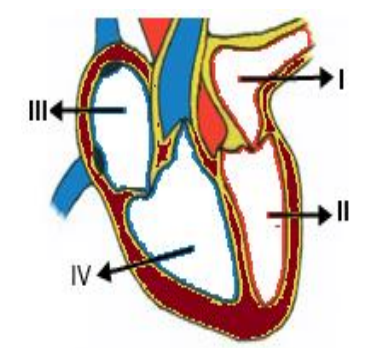

Which of the numbered parts contains the tricuspid valve?
A) I and II,
B) II and IV,
C) III and IV, 

D) I and III,
E) I and IV.

13) In humans

a) Aortic artery,

b) Pulmonary vein,

c) Pulmonary artery,

d) Upper main vein,

e) Lower main vein.

How many of the vessels above are involved in the large circulatory system?
A) 1 ,
B) 2,
C) 3 ,
D) 4 ,
E) 5 .

14) Teacher Hatice, in the Science course, asks her students, "What are the beginning and ending parts of the large circulatory system in the human heart?". Accordingly, which of the following options selected by students will be the correct answer of Teacher Hatice's question?
A) Right atrium - left ventricle,
B) Left atrium - right ventricle,
C) Left ventricle - right atrium,
D) Right ventricle - left atrium,
E) Left ventricle - left atrium.

15) Which of the following is wrong about the heart of a healthy person?
A) The human heart consists of four chambers.
B) Our heart muscles work against our will.
C) The heart is located in the thoracic cavity.
D) The heart contracts and relaxes, pumping blood throughout the body.
E) The heart is closer to the right lung.

16) Some characteristics of a vessel in the human circulatory system are:

- It comes out of the left ventricle.

- It carries oxygen-rich blood.

- It carries blood from the heart to the organs of the body.

To which of the following vessels do these characteristics belong?
A) Aortic artery,
B) Pulmonary vein,
C) Pulmonary artery,
D) Upper main vein, 

E) Pulmonary vein.

17) The human heart is schematized below.

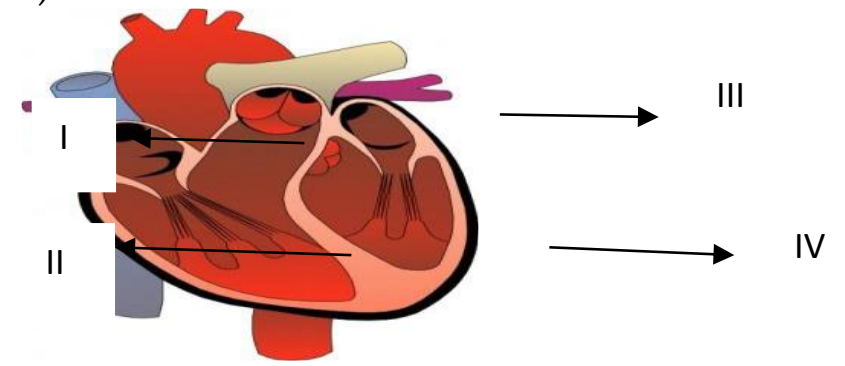

Which of the following statements about the numbered parts is wrong?
A) Part I is the right atrium.
B) Between Part I and II is the tricuspid valve.
C) The blood returning from the lungs comes to Part III of the heart.
D) When the blood in Part IV gets out of the heart, the large circulatory system begins.
E) Part III and IV contain oxygen-poor blood.

18) Which of the following is a common feature of the bicuspid valve and the tricuspid valve?
A) They are located between the right atrium and the left atrium.
B) They function in the flow of blood from the ventricles to the atria.
C) They function in the flow of blood from the atria to the ventricles.
D) They are located between the left ventricle and the right ventricle.
E) They function in the passage of blood into the arteries by contraction of the ventricles.

19) Which of the following statements about the structure of the human heart is wrong?
A) The endocardium consists of a thin epithelial layer.

B) The outermost pericardium has cardiac protective properties.

C) Between the two layers of the pericardium is pericardial fluid.

D) The myocardial thickness of the left ventricle is relatively greater than that of the right ventricle.

E) Valves provide bidirectional flow of blood.

20) Which of the following statements about the human circulatory system is wrong?

A) The circulatory system functions in bringing the substances needed by the cells into the cells and removing waste materials from the cells.

B) The circulatory system consists of blood, vessels and heart.

C) The pressure exerted by the blood on the arterial wall in the circulatory system is called blood pressure.

D) The feeling of the rhythmic contraction and relaxation of the heart in the arteries is called the pulse. 
E) All arteries in the circulatory system contain oxygen-rich blood.

Appendix 2: Augmented Reality Applications Attitude Scale

\section{Dear students,}

Indicate your views on the activities prepared with augmented reality on the subject of "Circulatory System" with one of the statements "Strongly Agree", "Agree", "Neither Agree nor Disagree", "Disagree" and "Strongly Disagree" (AR = Augmented Reality).

School: Karacadag Anatolian High School

Class/ Branch: 11-I

Gender: ( ) Female ( ) Male.

\begin{tabular}{|c|c|c|c|c|c|}
\hline Items & 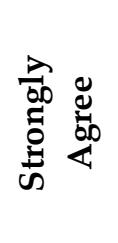 & 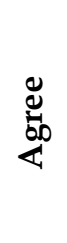 & 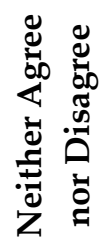 & 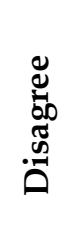 & 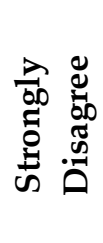 \\
\hline \multicolumn{6}{|l|}{ 1. I enjoy the lessons taught with AR activity. } \\
\hline \multicolumn{6}{|l|}{$\begin{array}{l}\text { 2. Thanks to the AR activity, I study more for the } \\
\text { lesson. }\end{array}$} \\
\hline \multicolumn{6}{|l|}{$\begin{array}{l}\text { 3. Displaying 3D objects, videos and animations on the } \\
\text { book in the AR activity increases my interest in the } \\
\text { subject. }\end{array}$} \\
\hline \multicolumn{6}{|l|}{$\begin{array}{l}\text { 4. In AR activity, 3D objects give a sense of reality in } \\
\text { the environment. }\end{array}$} \\
\hline \multicolumn{6}{|l|}{$\begin{array}{l}\text { 5. When AR activity is used, I come to the classroom } \\
\text { more willingly. }\end{array}$} \\
\hline \multicolumn{6}{|l|}{$\begin{array}{l}\text { 6. When AR activity is used, I can pay better attention } \\
\text { to the lesson. }\end{array}$} \\
\hline \multicolumn{6}{|l|}{ 7. I enjoy studying at home with the AR activity. } \\
\hline \multicolumn{6}{|l|}{ 8. I'm not interested in AR activity. } \\
\hline \multicolumn{6}{|l|}{$\begin{array}{l}\text { 9. AR activity makes it difficult for me to learn because } \\
\text { it confuses me. }\end{array}$} \\
\hline \multicolumn{6}{|l|}{ 10. There is no need to use AR activity in classes. } \\
\hline \multicolumn{6}{|l|}{$\begin{array}{l}\text { 11. Using AR activity in classes leads to a waste of } \\
\text { time. }\end{array}$} \\
\hline \multicolumn{6}{|l|}{ 12. I get bored when using the AR activity. } \\
\hline \multicolumn{6}{|l|}{ 13. It is difficult to use the AR activity. } \\
\hline \multicolumn{6}{|l|}{ 14. I want to use AR activities in other courses as well. } \\
\hline $\begin{array}{l}\text { 15. I want AR activities to be included in textbooks in } \\
\text { the future. }\end{array}$ & & & & & \\
\hline
\end{tabular}



to copy, distribute, transmit or adapt the article content, providing a proper, prominent and unambiguous attribution to the authors in a manner that makes clear that the materials are being reused under permission of a Creative Commons License. Views, opinions and conclusions expressed in this research article are views, opinions and conclusions of the author(s). Open Access Publishing Group and European Journal of Education Studies shall not be responsible or answerable for any loss, damage or liability caused in relation to/arising out of conflicts of interest, copyright violations and inappropriate or inaccurate use of any kind content related or integrated into the research work. All the published works are meeting the Open Access Publishing requirements and can be freely accessed, shared, modified, distributed and used in educational, commercial and non-commercial purposes under a Creative Commons Attribution 4.0 International License (CC BY 4.0). 